\title{
Did Foreign Direct Investment contribute to the Libyan Economic Growth in Transition Period?
}

\author{
Abderahman Efhialelbum \\ Management and Governance School - Murdoch University - Perth Western Australia. \\ E-mail: A.Efhialelbum@murdoch.edu.au \\ Paul Flatau \\ Business School - University of Western Australia - Perth Western Australia \\ paul.flatau@uwa.edu.au
}

\section{Doi:10.5901/mjss.2013.v4n9p46}

\section{Abstract}

Despite the large body of research about the impact of FDI on economic growth; the results have been elusive. Whereas, research shows positive impact on some countries; some research illustrates negative effect in other countries. Accordingly, this paper aims to examine the FDl's impact on the Libyan economy in the transition period 1990-2010. Also, the study compares the FDI performance in Libya and some countries in transition. I used many sorts of analyses such as: time-series analysis, correlation and regression analysis, to find out the impact of FDI on Libyan economy, and how the Libyan transitional economy followed the trajectory of other transitional economies in terms of FDI, and in what ways has it differed from other transitional economies. The research illustrates that the impact of FDI on Libyan economy was weak in transition period. Also, the comparison between Libyan FDI performance and some countries in transition shows dissimilarity in terms of FDI performance index. Furthermore, the study shows that the relationship between FDI annual change and GDP annual change in Libya was negative.

Keywords: FDI; economic growth; transition economy; Libya.

JEL classification: C22, F21, F43,

\section{Introduction}

The role of FDI in the economic growth has been at the heart of debate in developing countries such as Pakistan, India,Vietnam and many countries of transition in Central and Eastern Europe. Because the impact of foreign direct investment on economies mixed with a belief that FDI has a beneficial impact on economic growth; so this belief triggered a large body of literature about its impact on many economic features such as GDP, income, wealth, and productivity. A significant number of research (Benacek, Gronicki, Holland, \& Sass, 2000; Javed, Sher, Awan, \& Ashfaq, 2012; Ray, 2012)based on the assumption that FDI has a positive and effective role in economic growth. This fact has some merit on the surface; however the case of Libya seems quite different; where this impact was either weak or negative in the period between 1990 and 2010. Also, (Yousaf, Nasir, Naqvi, Haider, \& Bhutta, 2011)indicate that the effect of FDI on economic growth is negative in Pakistan.

Furthermore, foreign Direct Investment (FDI)has been considered not only a significant source of external resource flows of money, technology, know-how, to developing countries over the years but also a substantial part of capital formation in these countries. Therefore, we should know what is the key factor that leads to the success of FDI in the host countries? Economists believe that, a recipient developing country only achieves benefits from FDI once they have sufficient absorptive capacity related to human capital resource, financial systems, physical infrastructure, technological, and institutional development. Some policies that improve host country absorptive capacities such as good education and training are extremely recommended (Massoud, 2008; Nauyen, Duysters, Patterson, \& Sander, 2009).

If the mentioned conditions are being provided the host countries would have benefit from FDI inflows. Because it is well-established that, both policy-makers and economists believe that, the free flow of capital across national borders allows capital to seek out the highest rate of return. Furthermore, unrestricted capital inflows may also offer several other advantages. According to, (Feldstein, 2000) international flows of capital lower the risk faced by owners of capital by granting them to diversify their lending and investment. Also, the global integration of capital markets can contribute to 
the spread of best practices in corporate governance, accounting rules, and legal traditions. Furthermore, the global mobility of capital limits the ability of governments to pursue bad policies. Also, the FDI has its benefit on other features of economy for example; firstly FDI allows the transfer of technology particularly in the form of new varieties of capital inputs that cannot be achieved through financial investments or trade in goods and services. FDI can also promote competition in the domestic input market. Secondly, recipients of FDI often gain employee training in the course of operating the new businesses, which contributes to human capital development in the host country. Lastly, profits generated by FDI contribute to corporate tax revenues in the host country(Loungani \& Razin, 2001).

Despite the straightforwardness of the argument, empirical evidence on a positive relationship between FDI inflows and host country economic growth has been elusive. When a relationship between FDI and economic growth is established empirically it tends to be conditional on host country characteristics such as the level of human capital. Accordingly, this study aims to analyse the impact of FDI on Libyan economic growth. The period from 1990 to 2010 chareterised by the fluctuation from negative figures in 1990s to high numbers in the early years of this millenium. Many analyses have been used in this research such as time-series anaysis, correlation analysis and regression analysis to find out the relationship between the economic growth and the FDI inflows to Libya. Also, the other analyses were used to compare the impact of FDI on Libyan economy to other countries in transition in Eastern Europe. So, the results show that this impact was different between Libya and the mentioned countries.

\section{The Review of Literature}

Account of economic growth is a key question in economics; so this question brings to existence a large body of research. One of key factors that has a significant effect on economic growth in developing countries is FDI. Most research do not give a robustevidence about this impact. For example, whereas there was a positive effect of FDI on economic growth in India and some countries in Central and Eastern Europe; however FDI had a negative impact in Pakistan .It well-established that, the positive impact relies not only on technology which provides an important link between FDI inflows and host country economic growth, but also on Inflows of physical capital that increases the rate of economic growth. Accordingly, to benefit from FDI in terms of economic growth host countries should have good infrastructure, skilled worker to absorb the technology and physical capitals.

Obviously, the fluctuation of FDI inflows is the key reason of its impact on the economy. According to the UN Conference on Trade and Development the figures of FDI are fluctuating in the last fifteen years. For instance, total inflow of FDI in 1995 was only (300) billion, this number sharply increased in 2000 reached (1400) billion. Then after, in 2003 this figure plunged to (500) billion. In the period 2004 to 2007 the inflow of FDI significantly increased to (2000) billion. The report also illustrates that the transition economies acquire the lowest share of the FDI inflows. Chart -1 indicates these facts.

Chart 1. FDI inflows around the world 1995-2011: UNCTAD World FDI 2012 report

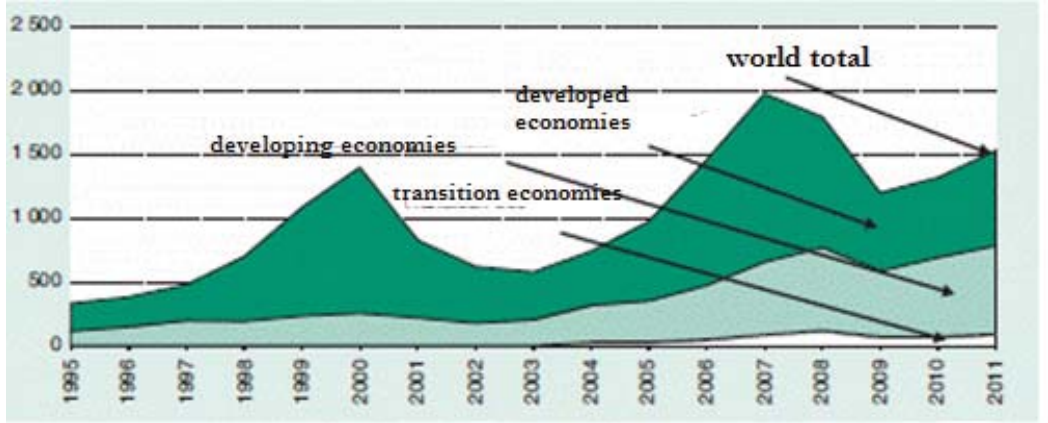

This fluctution of FDI could affect the impact of FDI on economic aspects around the world. Of course, the political factor is playing the key role in FDI inflow such as the Libyan case. Where the regime used the FDI for political purposes and somehow succeeded in this issue. For instance, whereas the regime was classified as sponsor ofterrorism by United Stated and most Western Countries in 1980s and 1990s; the regime became the intemate friend for those countries after 2004because of FDI regardless of the human rights and democracy. Chart 2 illustrates that the figures of FDI inflows to 
Libya fluctuating in the period of transition. Also, it can be seen that, figures in late 1990s were negative, and remarkably increased after 2004 when the economic sanctions have been lifted.

Chart 2. Foreign Direct Investment inflows in libya (1991) - (2009) (WorldBank, Various Issues)

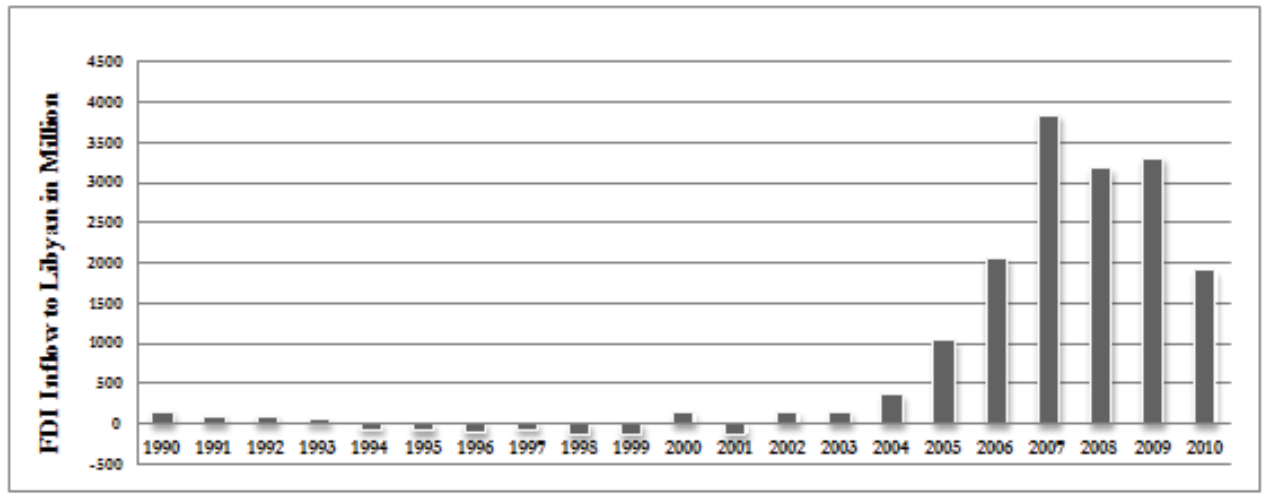

Obviously, the Libyan economy is highly dependent on oil and gas prices rather than any economic factors, for example agriculture contribute only 4 per cent of GDP (GAl, 2008). Also, the contribution of tourism to GDP in 2011 was -6.5 (WTTC, 2012). These facts show that the Libyan economy heavily dependent on natural resources. The chart -3 shows the direct relationship between the oil price and GDP. It can be seen that GDP increases when oil prices rise and vice versa. This might indicate that the impact of FDI on the Libyan economy is weak and its contribution was limited.

Chart 3. The relationship between Oil Price and GDP (OPEC, 2010) and (Mundi, 2012).

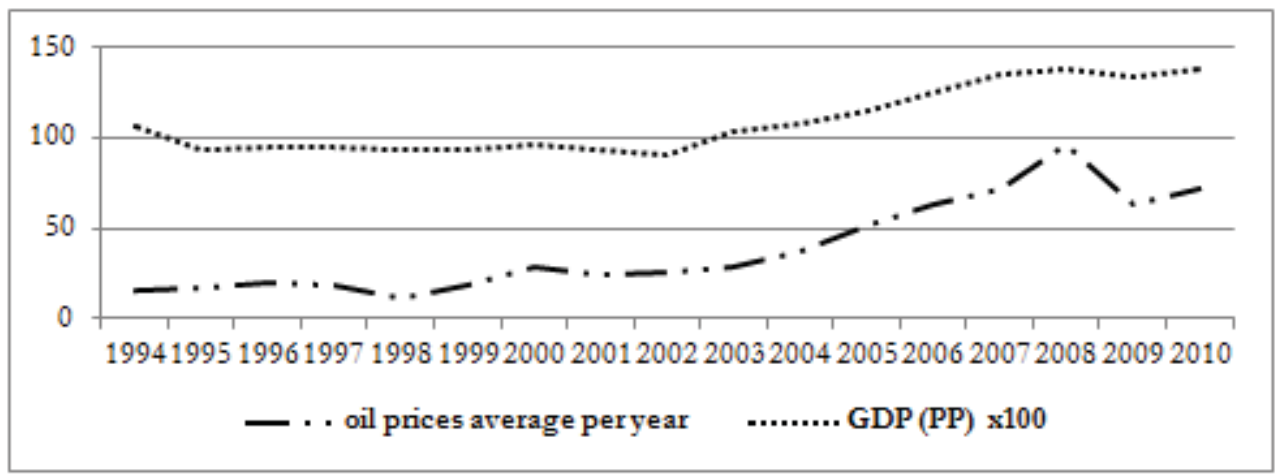

\section{Methodology}

The aim of this paper is to examine the relationship between economic growth and FDI in Libya using the annual data of the period, 1990 to 2010 which cover the 21 annual observations. The two main variables of this study are economic growth and FDI. The real Gross Domestic Product (GDP) is used as the proxy for economic growth in Libya and we represent the economic growth rate by using the constant value of Gross Domestic Product (GDP) measured in US dollar. All required data for the sample period is obtained from the international institutions such The World Bank, IMF and UNCTAD the United Nations Conference on Trade and Development. The study also compares the performance of FDI in Libya and some countries in transition in Eastern Europe. Accordingly, many analyses have been used in this study such as: time-serious analysis, regression analysis, the correlation analysis, ratio analysis, and standard deviation to find out the impact of FDI on Libyan economic, and how the Libyan transitional economy followed the trajectory of other transitional economies and in what ways has it differed from other transitional economies. 


\section{Analyses and Results}

The growth of international economic activities can be driven by both economic and technological components. It is also driven by the on-going liberalisation of Foreign Direct Investment (FDI) and trade policies. One prominent characteristic of this phenomenon is the circulation of private capital flow in the form of foreign direct investment (FDI) towards developing countries, especially after 1990s. According to International Monetary Fund (IMF), FDI refers to "an investment that is made to acquire a lasting interest in enterprises operating outside of the economy of the investor". Thus, the investor's purpose is to have an effective voice in the management of the enterprise. FDI is the process by which the residents of one country (the source country) acquire the ownership of assets for the purpose of controlling the production, distribution and other productive activities of a firm in another country (Ray, 2012).

Data from Libyan authorities on FDI is unavailable and difficult to obtain; accordingly, I resorted to the international institutions to find the required data. We believe that the period of international sanctions did not enormously affect the FDI inflow to Libya. My point of view, the sanctions were imposed only on flights and arms trades. Consequently, the response of the regime was to prevent the international companies from investing in Libyan territories. This fact is clearly seen from the negative figures of FDI in 1990s when the outflows of FDI exceeded inflows chart 2.

\subsection{Time series analysis:}

The data from Libya about foreign direct investment is fluctuating from negative figures to enormous numbers in the first decade of this millennium. Accordingly, we used this model to get meaningful results about the futurist impact of FDI on Libyan economy. So, we found that the time-series following the random component; which is often referred to as "noise" in the data. A time-series with no identifiable pattern is completely random and contains only noise (Groebner, Shannon, Fry, \& Smith, 2011). The following table shows the analysis of FDI for 21 years from $1990-2010$.

Table 1. time-series analysis of Libyan FDI inflows

\begin{tabular}{|c|c|c|c|c|c|c|c|c|}
\hline time & & FDI inflow & $\begin{array}{c}\text { Moving } \\
\text { means }\end{array}$ & $\begin{array}{c}\text { centred } \\
\text { moving } \\
\text { means }\end{array}$ & $\begin{array}{c}\text { Time } \\
\text { Period }\end{array}$ & $\begin{array}{c}\text { FDI } \\
\text { inflow } \\
\text { in } \\
\text { millions }\end{array}$ & $\begin{array}{c}\text { centred } \\
\text { moving } \\
\text { means }\end{array}$ & ISE \\
\hline $\mathbf{1 9 9 0}$ & 1 & 159.9 & & & 1 & 159.9 & & \\
\hline 1991 & 2 & 91.9 & & & 2 & 91.9 & & \\
\hline 1992 & 3 & 99.1 & & & 3 & 99.1 & & \\
\hline 1993 & 4 & 58.2 & 102.275 & 91.3625 & 4 & 58.2 & 91.3625 & -33.2 \\
\hline $\mathbf{1 9 9 4}$ & 5 & 72.6 & 80.45 & 80.025 & 5 & 72.6 & 80.025 & -7.4 \\
\hline $\mathbf{1 9 9 5}$ & 6 & 88.5 & 79.6 & 53.25 & 6 & 88.5 & 53.25 & 35.3 \\
\hline $\mathbf{1 9 9 6}$ & 7 & -111.7 & 26.9 & 11.1375 & 7 & -111.7 & 11.1375 & -122.8 \\
\hline $\mathbf{1 9 9 7}$ & 8 & -67.9 & -4.625 & -29.6875 & 8 & -67.9 & -29.6875 & -38.2 \\
\hline $\mathbf{1 9 9 8}$ & 9 & -127.9 & -54.75 & -49.8 & 9 & -127.9 & -49.8 & -78.1 \\
\hline $\mathbf{1 9 9 9}$ & 10 & 128.1 & -44.85 & -13.2625 & 10 & 128.1 & -13.2625 & 141.4 \\
\hline $\mathbf{2 0 0 0}$ & 11 & 141 & 18.325 & 43.4375 & 11 & 141 & 43.4375 & 97.6 \\
\hline $\mathbf{2 0 0 1}$ & 12 & 133 & 68.55 & 102.6625 & 12 & 133 & 102.6625 & 30.3 \\
\hline $\mathbf{2 0 0 2}$ & 13 & 145 & 136.775 & 138.6375 & 13 & 145 & 138.6375 & 6.4 \\
\hline $\mathbf{2 0 0 3}$ & 14 & 143 & 140.5 & 167.5 & 14 & 143 & 167.5 & -24.5 \\
\hline $\mathbf{2 0 0 4}$ & 15 & 357 & 194.5 & 307.625 & 15 & 357 & 307.625 & 49.4 \\
\hline $\mathbf{2 0 0 5}$ & 16 & 1038 & 420.75 & 660.625 & 16 & 1038 & 660.625 & 377.4 \\
\hline $\mathbf{2 0 0 6}$ & 17 & 2064 & 900.5 & 1363.875 & 17 & 2064 & 1363.875 & 700.1 \\
\hline $\mathbf{2 0 0 7}$ & 18 & 3850 & 1827.25 & 2180.125 & 18 & 3850 & 2180.125 & 1669.9 \\
\hline $\mathbf{2 0 0 8}$ & 19 & 3180 & 2533 & 2817 & 19 & 3180 & 2817 & 363.0 \\
\hline $\mathbf{2 0 0 9}$ & 20 & 3310 & 3101 & 3081.625 & 20 & 3310 & 3081.625 & 228.4 \\
\hline $\mathbf{2 0 1 0}$ & 21 & 1909 & 3062.25 & 3062.25 & 21 & 1909 & 3062.25 & -1153.3 \\
\hline
\end{tabular}

Source: World Bank 2011.ISE: individual seasonal effect. Centred moving means: A specified moving average is used to smooth time-series data. It forms a new smoothed series in which the irregular component is reduced. 
ISE is the individual seasonal effect is the difference between the raw data and the centred moving average. This is done for all available moving mean values. The individual seasonal effect is how far a data value is above or below the moving average. If the individual seasonal effect is positive the data value is above the moving average.

Chart 4. Time-series trends in Libyan FDI inflows

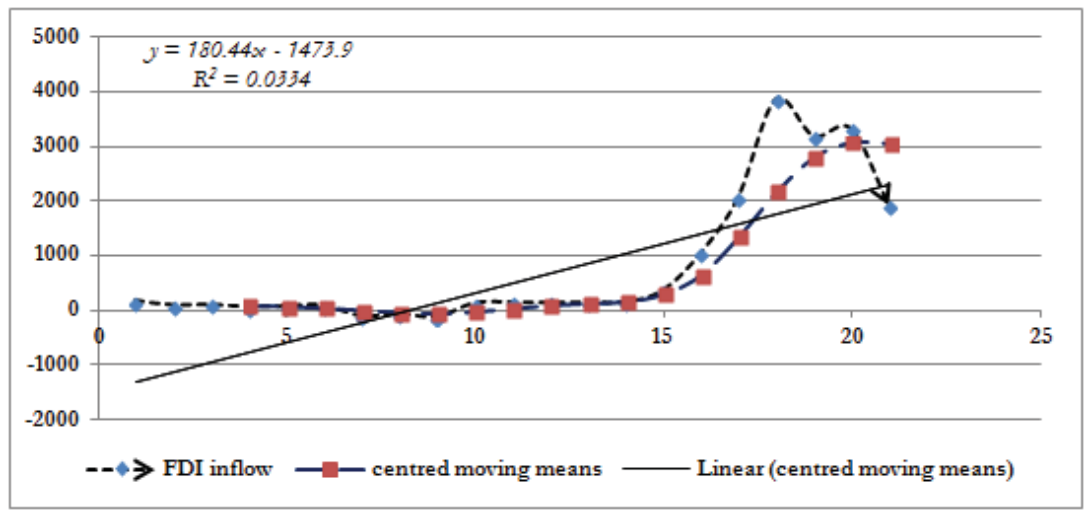

From the table and chart it can be seen that, the FDI to Libya fluctuated from negative figures such as -127.9 million in 1998 to 3,850 million in 2006. Making forecasting for the next years is very difficult for two reasons; firstly, the enormous fluctuation in data makes it difficult to forecast the forthcoming years. So, it's random component and contains only noise. Secondly, the overall transition in both political and economic features that happened in Libya after February 2011might have a different impact on FDI in the forthcoming years.

\subsection{FDI performance index}

According to (UNCTAD 2009), the Inward FDI Performance Index ranks countries by the FDI they receive relative to their economic size. It is the ratio of a country's share in global FDI inflows to its share in global GDP. A value greater than one indicates that the country receives more FDI than its relative economic size, a value below one that means the country receives less (a negative value means that foreign investors disinvest in that period). Thus the index illustrates the influence of FDI on factors rather than market size, assuming that, other things being equal, size is the "base line" for attracting investment. The other factors can be diverse, such as business climate, economic and political stability, the presence of natural resources, infrastructure, skills and technologies, to opportunities for participating in privatisation or the effectiveness of FDI promotion.

Therefore, we compare the FDI performance index among Libya and other countries in transition such as Latvia, Ukraine, Czech Republic, Poland, and Hungary. The following table shows data about these countries in terms of FDI performance index.

Table 2. FDI performance index in Libya and some countries in transition (UNCTAD, 2011)

\begin{tabular}{|c|c|c|c|c|c|c|}
\hline period & Libya & Latvia & Ukraine & Poland & Czech Rep & Hungary \\
\hline $1990-92$ & 0.497 & 3.586 & 1.256 & 0.634 & 2.332 & 4.13 \\
\hline $1991-93$ & 0.353 & 3.43 & 0.995 & 1.453 & 3.224 & 6.47 \\
\hline $1992-94$ & 0.108 & 4.747 & 0.729 & 1.87 & 2.862 & 5.001 \\
\hline $1993-95$ & -0.112 & 4.203 & 0.576 & 2.214 & 3.135 & 6.75 \\
\hline $1994-96$ & -0.306 & 4.96 & 0.7 & 2.373 & 2.832 & 5.289 \\
\hline $1995-97$ & -0.247 & 5.099 & 0.791 & 2.325 & 2.4 & 4.881 \\
\hline $1996-98$ & -0.213 & 4.284 & 0.792 & 2.022 & 2.196 & 2.693 \\
\hline
\end{tabular}




\begin{tabular}{|c|c|c|c|c|c|c|}
\hline 1997- 99 & -0.146 & 2.661 & 0.601 & 1.615 & 2.742 & 1.752 \\
\hline $\mathbf{1 9 9 8 - 0 0}$ & -0.124 & 1.62 & 0.505 & 1.391 & 2.665 & 1.157 \\
\hline $\mathbf{1 9 9 9 - 0 1}$ & -0.114 & 1.235 & 0.538 & 1.244 & 2.981 & 1.973 \\
\hline $\mathbf{2 0 0 0 - 0 2}$ & -0.137 & 1.377 & 0.662 & 1.179 & 3.583 & 1.954 \\
\hline $\mathbf{2 0 0 1 - 0 3}$ & 0.352 & 1.76 & 1.11 & 1.188 & 3.9 & 2.296 \\
\hline $\mathbf{2 0 0 2 - 0 4}$ & 0.339 & 2.053 & 1.378 & 1.251 & 3.07 & 2.081 \\
\hline $\mathbf{2 0 0 3 - 0 5}$ & 0.974 & 2.339 & 3.048 & 2.046 & 3.272 & 2.724 \\
\hline $\mathbf{2 0 0 4 - 0 6}$ & 1.285 & 2.727 & 2.63 & 2.138 & 2.701 & 2.626 \\
\hline
\end{tabular}

$$
I N D_{i}=\frac{\mathrm{FDI}_{\mathrm{i}} / F D I_{w}}{\mathrm{GDP}_{\mathrm{i}} / \mathrm{GDP}_{\mathrm{w}}}
$$

Where; INDi, the inward FDI performance index of the ith country. FDli, FDI inflows in the ithcountry.FDIw, world FDI inflows. GDPiGDI in the ith country.GDPw World GDP.

Regression coefficient and ANOVA analysis which used in this part is a parametric procedure used to determine the statistical significance of the difference between the means of two or more groups of values. By parametric, it is meant that the data is normally distributed in a normal or bell-shaped curve. Accordingly, it used to find out the relationship between the Libyan transition economy and other transition economies in Eastern Europe in terms of performance index. The coefficients with the exception of Ukraine ranging between $(-0.219$ and 0.067$)$ that means apart from Ukraine the relationship is very weak.

Table 3. Regression analysis of FDI performance index for Libya and some countries in transition

\begin{tabular}{|c|c|c|c|c|c|c|c|c|}
\hline \multicolumn{6}{|l|}{ ANOVA } & & & \\
\hline & $d f$ & SS & $M S$ & $F$ & $\begin{array}{c}\text { Significance } \\
F\end{array}$ & & & \\
\hline Regression & 5 & 2.8135 & 0.5627 & 18.76705 & 0.000161 & & & \\
\hline Residual & 9 & 0.269851 & 0.029983 & & & & & \\
\hline \multirow[t]{2}{*}{ Total } & 14 & 3.083351 & & & & & & \\
\hline & Coefficients & $\begin{array}{c}\text { Standard } \\
\text { Error }\end{array}$ & t Stat & $P$-value & Lower 95\% & $\begin{array}{c}\text { Upper } \\
95 \%\end{array}$ & $\begin{array}{l}\text { Lower } \\
95.0 \%\end{array}$ & $\begin{array}{l}\text { Upper } \\
95.0 \%\end{array}$ \\
\hline Intercept & 0.0317 & 0.5201 & 0.0610 & 0.9527 & -1.1449 & 1.2084 & -1.1449 & 1.2084 \\
\hline Latvia & -0.0593 & 0.0951 & -0.6240 & 0.5481 & -0.2745 & 0.1558 & -0.2745 & 0.1558 \\
\hline Ukraine & 0.5994 & 0.0654 & 9.1598 & 0.0000 & 0.4513 & 0.7474 & 0.4513 & 0.7474 \\
\hline Poland & -0.2186 & 0.1267 & -1.7247 & 0.1187 & -0.5052 & 0.0681 & -0.5052 & 0.0681 \\
\hline Czech Rep & -0.0686 & 0.1531 & -0.4483 & 0.6645 & -0.4150 & 0.2777 & -0.4150 & 0.2777 \\
\hline Hungary & 0.0667 & 0.0519 & 1.2864 & 0.2304 & -0.0506 & 0.1841 & -0.0506 & 0.1841 \\
\hline
\end{tabular}

Table 4. Correlation analyses for FDI performance index for Libyan and some countries in transition

\begin{tabular}{|l|l|l|l|l|l|l|}
\hline & Libya & Latvia & Ukraine & Poland & Czech & Hungary \\
\hline Libya & 1 & & & & & \\
\hline Latvia & -0.24596 & 1 & & & & \\
\hline Ukraine & 0.916748 & -0.16206 & 1 & & & \\
\hline Poland & -0.07341 & 0.619666 & 0.159626 & 1 & & \\
\hline Czech & 0.163345 & -0.52195 & 0.106306 & -0.2336 & 1 & \\
\hline Hungary & -0.10834 & 0.765823 & -0.14667 & 0.401162 & -0.07067 & 1 \\
\hline
\end{tabular}


Apart from Ukraine Correlation analysis of data refers to negative relation. Also, standard deviation refers to the same results. ANOVA analysis illustrates the same outcomes; where number of p-value in column 6 is big and (should be 0.05 or less).

Also, the chart -5 shows that the relationship among the Libyan FDI performance and some countries in transition is either negative or weak.

Chart 5. The linear relationship of FDI performance index between Libya and some countries in transition

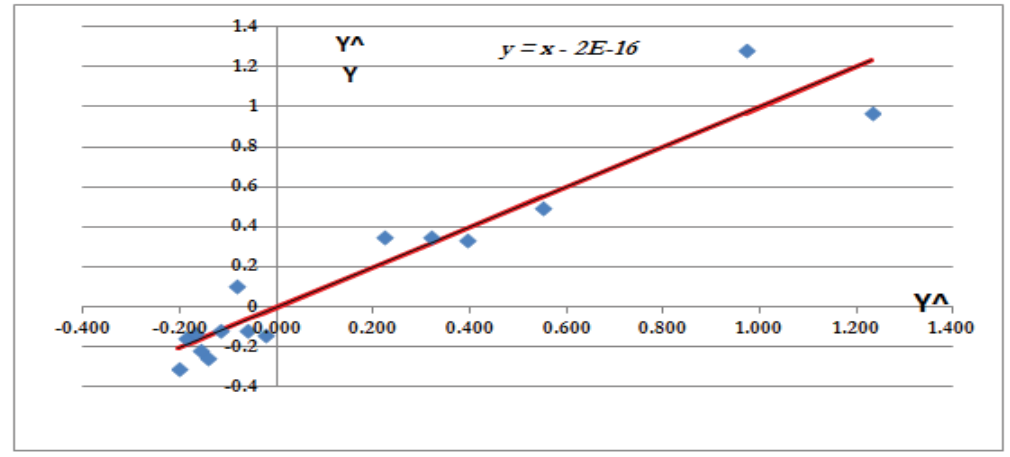

\subsection{FDI inward potential index}

This index evaluates the host country ability to attract FDI flows vis-à-vis other countries. So, the Inward FDI Potential Index captures several factors (apart from market size) expected to affect an economy's attractiveness to foreign investors. It is an average of the values of many variables: the rate of GDP growth over the previous 10 years, which is proxy for expected economic growth. Also, it includes the share of exports in GDP, to capture openness and competitiveness. Furthermore, this indicator considered as an indicator of modern information and communication infrastructure, and the share of R\&D spending in GDP, to capture local technological capabilities, the share of tertiary students in the population, indicating the availability of high-level skills, the world market share in exports of natural resources, to proxy for the availability of resources for extractive FDI. This indicator may include the share of world FDI inward stock, a broad indicator of the attractiveness and absorptive capacity for FDI, and the investment climate. The following table shows the FDI potential index for Libya and some countries in transition. I use the linear regression analysis to find out the relationship between these countries in terms of FDI potential index.

Table 5. FDI potential index for Libya and some countries in transition

\begin{tabular}{|c|c|c|c|c|c|c|}
\hline Period & Libya & Russia & Ukraine & Poland & Czech & Hungary \\
\hline $1990-1992$ & 0.208 & 0.259 & 0.204 & 0.183 & 0.184 & 0.182 \\
\hline $1991-1993$ & 0.209 & 0.248 & 0.181 & 0.189 & 0.196 & 0.183 \\
\hline $1992-1994$ & 0.202 & 0.252 & 0.181 & 0.193 & 0.212 & 0.186 \\
\hline $1993-1995$ & 0.202 & 0.274 & 0.201 & 0.212 & 0.249 & 0.21 \\
\hline $1994-1996$ & 0.192 & 0.263 & 0.182 & 0.211 & 0.249 & 0.211 \\
\hline $1995-1997$ & 0.185 & 0.262 & 0.177 & 0.214 & 0.24 & 0.213 \\
\hline $1996-1998$ & 0.248 & 0.263 & 0.173 & 0.251 & 0.258 & 0.238 \\
\hline $1997-1999$ & 0.241 & 0.272 & 0.166 & 0.253 & 0.262 & 0.245 \\
\hline $1998-2000$ & 0.24 & 0.291 & 0.157 & 0.253 & 0.263 & 0.247 \\
\hline $1999-2001$ & 0.267 & 0.281 & 0.153 & 0.248 & 0.259 & 0.258 \\
\hline $2000-2002$ & 0.254 & 0.291 & 0.156 & 0.256 & 0.263 & 0.269 \\
\hline $2001-2003$ & 0.28 & 0.32 & 0.191 & 0.252 & 0.268 & 0.267 \\
\hline $2002-2004$ & 0.257 & 0.344 & 0.217 & 0.255 & 0.265 & 0.271 \\
\hline $2003-2005$ & 0.269 & 0.36 & 0.24 & 0.255 & 0.271 & 0.265 \\
\hline $2004-2006$ & 0.298 & 0.379 & 0.26 & 0.264 & 0.277 & 0.269 \\
\hline
\end{tabular}


Table 6. Regression analysis of FDI potential index for Libya and some countries in transition

\begin{tabular}{|c|c|c|c|c|c|c|c|c|}
\hline \multicolumn{6}{|l|}{ ANOVA } & \multirow[b]{6}{*}{$\begin{array}{l}\text { Upper } \\
95 \%\end{array}$} & \multirow[b]{6}{*}{$\begin{array}{l}\text { Lower } \\
95.0 \%\end{array}$} & \multirow[b]{6}{*}{$\begin{array}{l}\text { Upper } \\
95.0 \%\end{array}$} \\
\hline & $d f$ & SS & MS & $F$ & $\begin{array}{c}\text { Significance } \\
F\end{array}$ & & & \\
\hline Regression & 5 & 0.015166 & 0.003033 & 13.87892 & 0.000525 & & & \\
\hline Residual & 9 & 0.001967 & 0.000219 & & & & & \\
\hline \multirow[t]{2}{*}{ Total } & 14 & 0.017132 & & & & & & \\
\hline & Coefficients & $\begin{array}{c}\text { Standard } \\
\text { Error }\end{array}$ & $t$ Stat & $P$-value & Lower 95\% & & & \\
\hline Intercept & 0.01397 & 0.05015 & 0.27852 & 0.78690 & -0.09947 & 0.12741 & -0.09947 & 0.12741 \\
\hline Russia & 0.13714 & 0.55061 & 0.24907 & 0.80890 & -1.10844 & 1.38272 & -1.10844 & 1.38272 \\
\hline Ukraine & 0.16672 & 0.46744 & 0.35668 & 0.72955 & -0.89069 & 1.22414 & -0.89069 & 1.22414 \\
\hline Poland & 1.19419 & 0.67014 & 1.78199 & 0.10844 & -0.32178 & 2.71015 & -0.32178 & 2.71015 \\
\hline Czech & -0.99456 & 0.38198 & -2.60368 & 0.02857 & -1.85866 & -0.13046 & -1.85866 & -0.1304 \\
\hline Hungary & 0.51241 & 0.76909 & 0.66626 & 0.52196 & -1.22740 & 2.25223 & -1.22740 & 2.25223 \\
\hline
\end{tabular}

Table 7. Correlation analysis of FDI potential index.

\begin{tabular}{|l|l|l|l|l|l|l|l|}
\hline & Libya & Russia & Ukraine & Poland & Czech & Hungary & $\begin{array}{l}\text { Standard } \\
\text { deviation }\end{array}$ \\
\hline Libya & 1 & & & & & & \\
\hline Russia & 0.796804 & 1 & & & & & 0.0464 \\
\hline Ukraine & 0.343839 & 0.735811 & 1 & & & & 0.0404 \\
\hline Poland & 0.842888 & 0.697037 & 0.108647 & 1 & & & 0.0314 \\
\hline Czech & 0.68264 & 0.668488 & 0.143309 & 0.927244 & 1 & & 0.0316 \\
\hline Hungary & 0.867 & 0.770834 & 0.175375 & 0.96912 & 0.905557 & 1 & 0.0337 \\
\hline
\end{tabular}

In terms of FDI potential index figures refers to a positive relationship in the mentioned countries in transition. Correlation is significantly big except Ukraine where the relationship is positive but weak. Also, standard deviation indicated to consistency in figures, and low scatter of the values.

From the tables (6) and (7) and chart (6) it can be seen that the relationship between the variables are positive. This does not mean that the performance is very good but the relationship between these countries is very strong. However, if a comparison has been made between Libya and some developed countries in terms of FDI potential index such as Australia, Germany and Singapore in the period 1998 to 2006 correlation results would be $(-0.707,-0.540$, and 0.418 ) respectively, that is negative relationship between these economies in terms of FDI potential index.

Chart 6. The linear relation between FDI potential index in Libya and some countries of transition

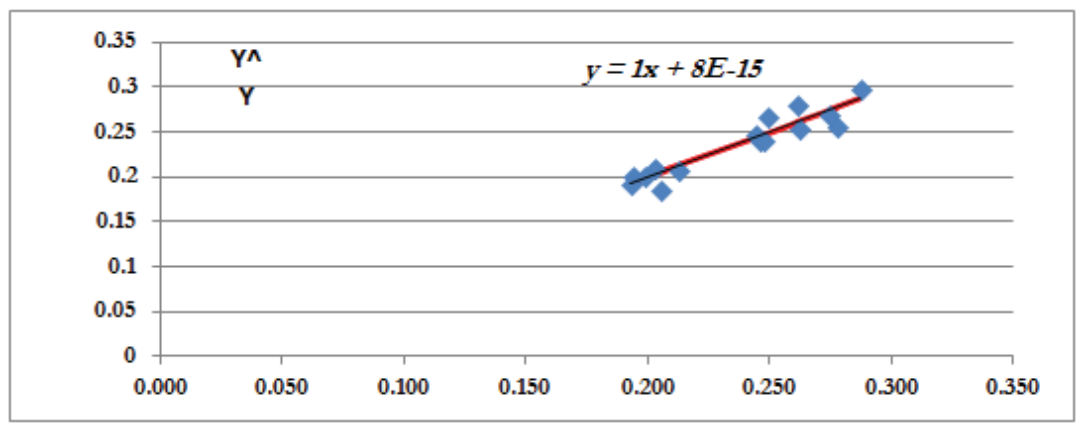

From the linear regression analysis and the chart it can be seen that, there is a positive relationship. 


\subsection{FDI/GDP Ratio}

FDI normalized by the size of the host economy which is an indicator of the attractiveness of an economy to draw FDI (Quader, 2010). A country with a ratio of FDI to GDP that is greater than one is reckoned to have received more FDI than that implied by the size of its economy. It indicates that the country may have a comparative advantage in production or better growth prospects reflecting larger market size for the foreign firm. On the other hand, a country that has the ratio value of less than one may be more protectionist and technologically backward, or may possess a political and social regime that is not conducive for investments. Overall, FDI-GDP ratio is an index of the prevailing investment climate in the host economy. Table (8) illustrates this index in case of Libya

Table 8. The FDI/GDP ratio and GDP real growth (UNCTAD 2011, World Bank 2010)

\begin{tabular}{|c|c|c|c|c|c|}
\hline & FDI inflows & GDP & FDI/GDP Ratio & FDI Change Rate & GDP Change Rate \\
\hline $\mathbf{1 9 9 1}$ & 91900000 & 28904898118 & 0.32 & & \\
\hline $\mathbf{1 9 9 2}$ & 99100000 & 31992732972 & 0.31 & 8.90 & 10.68 \\
\hline $\mathbf{1 9 9 3}$ & 58200000 & 30660051911 & 0.19 & -41.27 & -4.17 \\
\hline $\mathbf{1 9 9 4}$ & 72600000 & 28610549763 & 0.25 & 24.74 & -6.68 \\
\hline $\mathbf{1 9 9 5}$ & 88500000 & 25541379187 & 0.35 & 21.90 & -10.73 \\
\hline $\mathbf{1 9 9 6}$ & -111700000 & 27884615385 & -0.40 & -226.21 & 9.17 \\
\hline $\mathbf{1 9 9 7}$ & -67900000 & 30700897875 & -0.22 & -39.21 & 10.10 \\
\hline $\mathbf{1 9 9 8}$ & -127900000 & 27251534530 & -0.47 & 88.37 & -11.24 \\
\hline $\mathbf{1 9 9 9}$ & 128100000 & 30484399896 & 0.42 & -200.16 & 11.86 \\
\hline $\mathbf{2 0 0 0}$ & 141000000 & 33896600871 & 0.42 & 10.07 & 11.19 \\
\hline $\mathbf{2 0 0 1}$ & 133000000 & 28420321952 & 0.47 & -5.67 & -16.16 \\
\hline $\mathbf{2 0 0 2}$ & 145000000 & 19842519685 & 0.73 & 9.02 & -30.18 \\
\hline $\mathbf{2 0 0 3}$ & 143000000 & 24062500000 & 0.59 & -1.38 & 21.27 \\
\hline $\mathbf{2 0 0 4}$ & 357000000 & 33384615385 & 1.07 & 149.65 & 38.74 \\
\hline $\mathbf{2 0 0 5}$ & 1038000000 & 44000000000 & 2.36 & 190.76 & 31.80 \\
\hline $\mathbf{2 0 0 6}$ & 2064000000 & 56484375000 & 3.65 & 98.84 & 28.37 \\
\hline $\mathbf{2 0 0 7}$ & 3850000000 & 71803278689 & 5.36 & 86.53 & 27.12 \\
\hline $\mathbf{2 0 0 8}$ & 3180000000 & 93167701863 & 3.41 & -17.40 & 29.75 \\
\hline $\mathbf{2 0 0 9}$ & 3310000000 & 62360446571 & 5.31 & 4.09 & -33.07 \\
\hline
\end{tabular}

$R^{2}=6$ percent. This refers to the heterogeneity of the figures. Also, by calculation the correlation between these figures it is only 0.24 which less than 30 percent referring to the weak relationship between FDI and GDP annual change.

Chart -7 the linear relationship of FDI/GDP annual change

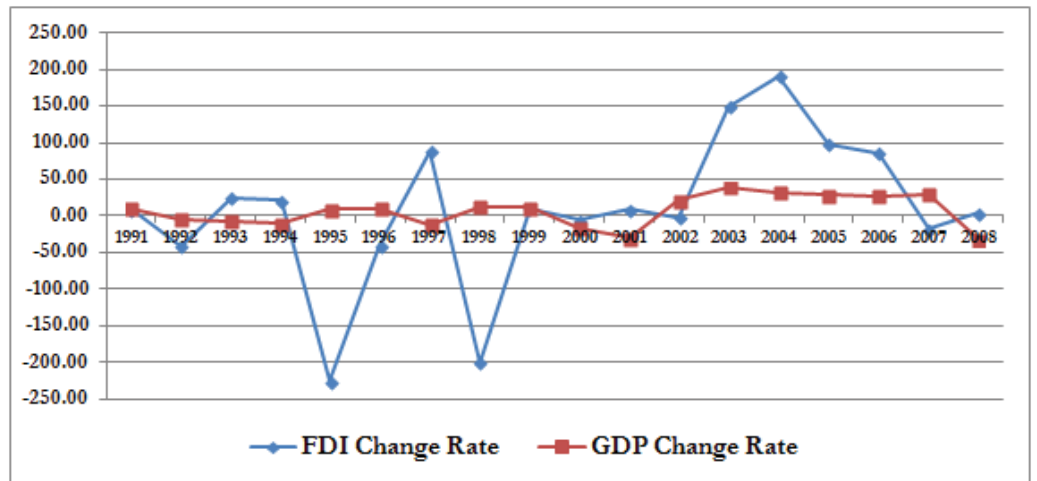

The table indicates that $R^{2}$ is very low $=6$ percent illustrating that relationship between the mentioned variable (FDI/GDP ratio and GDP growth) is very weak. Furthermore, the correlation between the percentage change of GDP and FDI is 
very weak. Where, this number is less than 30 percent. That is, the impact of the FDI on economic growth is very limited.

\section{Conclusion}

Despite the remarkable role of FDI in the economic growth in many countries around the world; its contribution to the Libyan economy seems very weak. This can be seen in the first years of transition from the socialism to the free-market. Therefore, the fluctuation of FDI figures makes forecasting the forthcoming years difficult or may be impossible. Furthermore, the study reveals that Libyan economy did not follow the trajectory of other countries in transition in terms of FDI. For example, the performance index is unlike to those in Eastern Europe. The similarity in terms of FDI does not mean that these countries including Libya do very good; because the comparison with other countries such as Australia, Germany, and Singapore refers to negative relationship. Also, FDI/GDP ratio is indicates that, the ratio is very low or even negative in the period from 1996-1998. That is, the impact of FDI on Libyan economy is weak. Finally, the generalisation of the notion of the positive impact of FDI on economic growth is very sensitive issue. Because every country has its own political and economic factors and environment, and each case (country) should be studied separately.

\section{References}

Benacek, V., Gronicki, M., Holland, D., \& Sass, M. (2000). The Determinants and Impact of Foreign Direct Investment in Central and Eastern Europe: A comparison of survey and econometric evidence. Transnational Corporations, Journal of United Nations, 9(3), 163-212.

Feldstein, M. (2000). Aspects of Global Economic Integration: Outlook for the Future. NBER Working Paper No. 7899, Cambridge, Massachusetts: National Bureau of Economic Research.

GAI. (2008). Statistics Book. Tripoli: General Authority for Information.

Groebner, D., Shannon, P., Fry, P., \& Smith, K. (2011). Business Statistics A Decision-Making Approach (Vol. eigth edition). Boston: Prentice Hall.

Javed, K., Sher, F., Awan, R., \& Ashfaq, M. (2012). Foreign Direct Investment, Trade and Economic Growth: A Comparison of Selected South Asian Countries International Journal of Humanities and Social Science, 2(5), 211-220.

Loungani, P., \& Razin, A. (2001). How Beneficial Is Foreign Direct Investment for Developing Countries? Finance and Development; A Quarterly Magazine of the IMF, 38.

Massoud, N. (2008). Assessing the Employment Effect of FDI Inflows to Egypt: Dose the Mode of Entry Matter? . Paper presented at the The Unemployment Crisis in the Arab Countries, Egypt.

Mundi, Index. (2012). Country GDP per captia (Libya) (Online Database). Retrieved 2012, from Index Mundi

Nauyen, H., Duysters, G., Patterson, J., \& Sander, H. (2009). Foreign Direct Investment Absorptive Capacity Theory. Paper presented at the 7 th International Conference: Globalisation and the building of absorptive capacity, Dakar.

OPEC. (2010). Annual Statistical Bulletin. In O. o. t. P. E. Countries (Ed.). Vienna: Organization of the Petroleum Exporting Countries.

Quader, S. (2010). Foreign Direct Investment in Bangladesh: An Empirical Analysis on its Determinants and Impacts. Asian Economic Review, 1(52), 1-16.

Ray, S. (2012). Impact of Foreign Direct Investment on Economic Growth in India: A Co integration Analysis. Advances in Information Technology and Management, 2(1), 187-201.

UNCTAD. (2011). Non-Equity Modes of International Production and Development. United Nations Conference on Trade and Development.

WorldBank. (Various Issues). Foreign direct investment, net inflows.http://data.worldbank.org/indicator/BX.KLT.DINV.CD.WD.

WTTC. (2012). Travel and Tourism Economic Impact 2012 Libya. World Travel and Tourism Council.

Yousaf, U., Nasir, A., Naqvi, F., Haider, A., \& Bhutta, N. (2011). Impact of Foreign Direct Investment on Economic Growth of Pakistan. European Journal of Economics, Finance and Administrive Science(32), 95-100. 